\title{
Does Firm's Board Affects ESG? Malaysian Evidence
}

\section{Sunarti Halid, Radziah Mahmud, Mohd Taufik Mohd Suffian, Rahayu Abdul Rahman}

To Link this Article: http://dx.doi.org/10.6007/IJARAFMS/v12-i1/11609 DOI:10.6007/IJARAFMS /v12-i1/11609

Received: 10 November 2021, Revised: 16 December 2021, Accepted: 29 December 2021

Published Online: 19 January 2022

In-Text Citation: (Halid et al., 2022)

To Cite this Article: Halid, S., Mahmud, R., Suffian, M. T. M., \& Rahman, R. A. (2022). Does Firm's Board Affects ESG? Malaysian Evidence. International Journal of Academic Research in Accounting Finance and Management Sciences, 12(1), 131-143.

Copyright: (c) 2022 The Author(s)

Published by Human Resource Management Academic Research Society (www.hrmars.com)

This article is published under the Creative Commons Attribution (CC BY 4.0) license. Anyone may reproduce, distribute, translate and create derivative works of this article (for both commercial and non-commercial purposes), subject to full attribution to the original publication and authors. The full terms of this license may be seen

at: http://creativecommons.org/licences/by/4.0/legalcode

Vol. 12, No. 1, 2022, Pg. 131 - 143

Full Terms \& Conditions of access and use can be found at http://hrmars.com/index.php/pages/detail/publication-ethics 


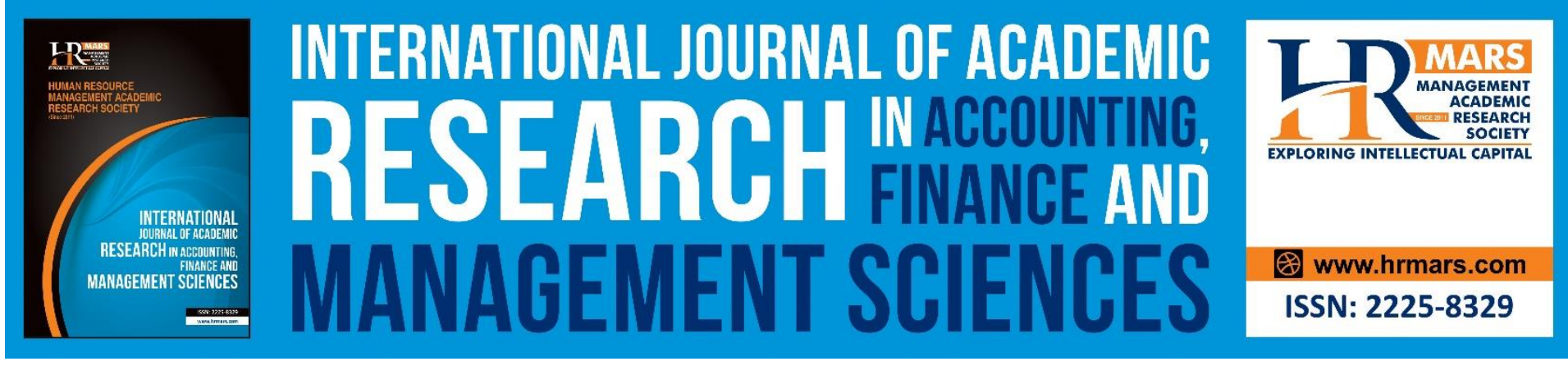

\title{
Does Firm's Board Affects ESG? Malaysian Evidence
}

\author{
Sunarti Halid ${ }^{1}$, Radziah Mahmud², Mohd Taufik Mohd Suffian³ \\ Rahayu Abdul Rahman ${ }^{4}$ \\ 1,3,4 Faculty of Accountancy, Universiti Teknologi MARA, Perak Branch, Tapah Campus, \\ Malaysia, ${ }^{2}$ Faculty of Accountancy, Universiti Teknologi MARA, Selangor Branch, Puncak \\ Alam Campus, Malaysia \\ Corresponding Author Email: rahay916@uitm.edu.my
}

\begin{abstract}
Non-financial information such as environmental, social, and governance (hereafter ESG) issues are becoming important as financial data. There has been a series of organizational failures and controversies about corporate governance, which have raised questions about the capabilities of management and ethical behaviour on the business's level of transparency. Even factors that influence or detract from an ESG score are becoming increasingly relevant to consider. Therefore, this study aims to investigate the relationship between board characteristics and ESG score in Malaysian listed firms. In particular, this study examines four important board charactristics; board size, board independence, tenure, and board diversity on ESG score. Using 165 firm- year observations from 2017 to 2019, the findings reveal that the board independence is significantly positively associated with ESG scores. Other board characteristics; board size, tenure and board diversity, however, is not associated with ESG score. Several control variables, namely firm size, profitability, and leverage have been considered in the study, and it found that all control variables have a significant impact on ESG scores. This study contributes to the governance and ESG literature in the developing countries byhighlighting the effect of board characteristics on firm's ESG scores.
\end{abstract}

Keywords: Board Size, Board Independence, Board Tenure, Board Diversity, ESG Score

\section{Introduction}

The firm's success depends on the board of directors. They are responsible for approving and overseeing the implementation of strategic goals, the system of governance and creating company culture (Birindelli et al., 2018). In another perspective, investors and stakeholders became more aware of non-financial reporting and cared about financial results and societal expectations; therefore, resource allocation became more complex. Firms are forced to allocate their resources to environmental and social issues and invest for better financial results and growth. Environmental, social and governance (hereafter ESG) is the quantifiable measure of a company's sustainability and societal impact, using metrics that matter to investors. There are three ESG score aspects: environmental, social, and governance in a single score. Each aspect has its indicators to assess the corporate sustainability performance. 
MANAGEMENT SCIENCES

Vol. 12, No. 1, 2022, E-ISSN: 2225-8329 @ 2022 HRMARS

Using a new measurement that has incorporated three aspects of corporate social responsibility, the ESG score can be used by investors as a tool to evaluate corporate sustainability performance more comprehensively (Zuraida et al., 2016).Malaysia is an essential sample for ESG research since Malaysian companies started implementing their first Corporate Social Reporting (hereafter CSR) Framework in 2006, which is mandatory for all firms in Malaysia, followed by the Sustainability Framework in 2015, which required ESG disclosures of the firms. The Companies Act 2016 also enforced CSR disclosures resulting in very high scores for CSR in Malaysian firms. The Malaysian government's effort in integrating CSR into its Tenth Malaysia Plan highlights the government's involvement in ensuring the implementation and success of CSR.

Therefore, the study aims to analyze whether the firm's board characteristics might influence ESG scores. To assess this relation, we analyzed fifty-five (55) Malaysian listed firms for 20172019. The board characteristics analyzed are size, independence, tenure, and diversity. The results obtained have shown that the only governance structure that influences the ESG score is the board independence. This study also considers four control variables: the firms' size, profitability, and leverage. We find that all control variables have a significant influence on the ESG score.

The remainder of the paper is presented as follows. The following section reviews the relevant literature and research hypotheses. In the third section, we present the sample, variables, and methodology used in estimating the model. The fourth section lays out the findings and empirical results. In the last section, we present our conclusion and limitations.

\section{Literature Review and Hypothesis Development}

Understanding why the board of directors should oversee ESG issues is the first step. The board should focus on balancing meeting the interest of its stakeholders and being accountable to them. Forward-looking firms value being a frontrunner on ESG issues because they see the connection to its long-term success. The literature explains the relationship between Board and ESG based on two dominant theories: agency theory (Jensen \& Meckling, 1976) and stakeholder theory (Freeman, 1984).

Agency theory described the presence of fundamental problems in principal-agent relationships. A conflicted relationship can arise when the agent's goals differ from the principle's (Naciti, 2019). A conflicted relationship can arise when the agent's goals differ from those of the principal. Therefore, agency theory suggests separating decision-making and reducing the manager's discretion (Fama \& Jensen, 1983).

Next, stakeholder's theory is the main theoretical principle of unpinning corporate governance and sustainability concerning this study. Freeman (1984) defines a stakeholder in an organization as "any group or individual who can affect or is affected by the achievement of the organization's objectives" (p. 46). This approach adhered to a priori literature consensus that stakeholder theory is the most appropriate for examining a firm's sustainability disclosure (Ismail \& Latif, 2019).

Therefore, the variables most widely used in the literature to describe the impact of board characteristics on ESG scores are related to the size of the board of directors, board 
MANAGEMENT SCIENCES

Vol. 12, No. 1, 2022, E-ISSN: 2225-8329 @ 2022 HRMARS

independence, board tenure and board gender diversity. In the sub-sections below, we develop our hypotheses for each of these characteristics of the board.

\section{Size of the Board of Directors}

Board size represents the total number of directors' seats in the corporate box. The size of the board impacts the independence of the board and the quality of corporate governance. Smaller boards are more effective in decision-making and have more individual responsibility regarding their monitoring obligation (Ahmed et al., 2006). In addition, smaller boards have fewer conflicts within the Board of directors because there is a smaller chance of in-group and out-group rivalry due to the lack of diversity and more collaboration between all board directors (Ahmed et al., 2006). However, due to the lack of diversity, it is less likely that the Board will focus on ESG policy (Bear et al., 2010).

On the other hand, larger boards bring in more diversity (gender, expertise, and education), leading to a broader perspective and a thought-out policy (Rao \& Tilt, 2016). It lowers the workload and makes it possible to divide tasks to directors who have the expertise. The increased board size will contribute to greater diversity in stakeholder representation and positively influence ESG performance. Because of the robust findings in the previous literature, this study expects to find a positive relation between board and ESG scores. Therefore, the following hypothesis is derived:

Hypothesis 1: There is a positive relationship between the size of the Board and the ESG score.

\section{Independence of the Board of Directors}

An independent board is an essential mechanism to control managers' actions and ensure shareholders' goals are accomplished. For the Board to function well, it is optimal to have a balanced board between executive directors and independent directors (Ismail \& Latiff, 2019). Because the interest of both kinds of directors is different from each other, their advice and decision making are different. Executive directors manage the company closely because they possess direct information. Additionally, they can be influenced by the Chief Executive Officer (CEO). Independent directors have an oversight role in the Board because there is no short-term financial incentive linked to their performance. Therefore, they function as an effective monitor and have more awareness of the social impact of the company (Brindelli et al., 2018).

Independent directors often link with stakeholders, attracting assets that contribute to a better relationship (Mallin \& Michelon, 2011). If the Board is well-balanced, the differences in interest give a better chance of providing the right advice for the short and long run of the company (Ismail \& Latiff, 2019). The influence of independent directors on sustainability performance is positive in multiple scholars (Zhang et al., 2013), (Shaukat et al., 2016), (Johnson \& Greening, 1999). The study of Johnson and Greening (1999) concluded that independent directors act in the long-term interest of shareholders. Considering these divergent views, we propose the following hypothesis:

Hypothesis 2: There is a positive relationship between the independence of the Board of Directors and the ESG score. 
MANAGEMENT SCIENCES

Vol. 12 , No. 1, 2022, E-ISSN: 2225-8329 @ 2022 HRMARS

\section{Board Tenure}

Tenure measures the number of years the current CEO has served as the firm's CEO in a year. According to Shiah-Hou and Cheng (2012), tenure is the length of time a director holds the office of a director in an organization. Existing literature reveals mixed results on tenure diversity; for example, Handajani et al. (2014) contend that more extended board members' service lowers CSR activities. Harjoto et al. (2015) found an insignificant influence of tenure diversity on CSR strength. Hafsi and Turgut (2013) also presented an insignificant relationship between tenure diversity and CSR performance. Therefore, the following hypothesis is proposed:

Hypothesis 3: There is a positive relationship between board tenure and ESG score.

\section{Diversity}

Researchers are interested in exploring the roles of female directors from various perspectives (Haque, 2017), especially in their involvement in the social and environmental context. Based on Huse and Grethe Solberg (2006), female directors are more involved, diligent, and committed and less self-oriented in making any decision for the company, thus enhancing the effectiveness of the board or its directors. Females are more likely to participate in environmental programs that would enable them to contribute to social, environmental, and sustainable development. Insofar, the following hypothesis was conducted:

Hypothesis 4: There is a positive relationship between the diversity of board members and the ESG score.

\section{Research Methodology}

\section{Sample Selection and Data Sources}

Refinitiv Eikon Datastream (formerly known as Thomson Reuters Eikon) is the most reliable and comprehensive international financial and accounting data (Refinitiv Eikon Datastream, 2021). Data for ESG scores are retrieved from Refinitiv Eikon Datastream. The availability of an ESG score on that database serves as the starting point for our sampling procedure. Market participants can use ESG scores as information that incorporates all relevant information about the company's sustainability. At present, there are sixty-four (64) Malaysian listed firms under Refinitiv ESG coverage. Excluding the missing values, we obtained a final sample of fiftyfive (55) listed Malaysian firms, for which data on ESG score was available on the date of analysis. We collected data for three years, including hundred sixty-five (165) firm-year observations (2017 to 2019), because, at the time of writing, data for the fiscal year 2020 was not fully available yet, as the Covid-19 pandemic postponed shareholders' meetings. Refinitiv is also used for financial information, while governance data are hand-collected for each firm from the annual governance report.

\section{Dependent Variable}

To test our hypothesis, we used data on ESG scores (ESG) from Refinitiv. ESG scores from Refinitiv are designed to measure relative ESG performance, commitment, and effectiveness of a company's transparently and objectively across ten (10) main themes (emissions, environmental product innovation, human rights, shareholders, etc.) based on publicly reported data. The score is expressed from 0 to 100 per cent. The higher score was associated 
MANAGEMENT SCIENCES

Vol. 12, No. 1, 2022, E-ISSN: 2225-8329 @ 2022 HRMARS

with a higher level of firm sustainability. At present, there are sixty-four (64) Malaysian listed firms under Refinitiv ESG coverage. ESG score of Refinitiv Eikon is extensively used by several researchers in their studies (Bae et al., 2021; Batae et al., 2021; Shakil, 2021). To capture the impact of board characteristics on ESG score with time for the effects to appear and lessen endogeneity problems, governance variables of any year are related to ESG measure of the following year.

\section{Independent Variables}

The independent variables include the board size, board independence, average board tenure, and diversity. The operationalizations for the independent variables are as per Table 1.

Table 1. Definition and Operationalization of Independent Variables.

\begin{tabular}{|c|c|c|}
\hline $\begin{array}{l}\text { Independent } \\
\text { Variables }\end{array}$ & Definition & Operationalization \\
\hline BSIZE & $\begin{array}{l}\text { Size of the Board of } \\
\text { Directors }\end{array}$ & $\begin{array}{l}\text { The total number of board members } \\
\text { at the end of the fiscal year (Arayssi } \\
\text { et al., 2020) }\end{array}$ \\
\hline IND & $\begin{array}{l}\text { Independence of the } \\
\text { Board of Directors }\end{array}$ & $\begin{array}{l}\text { The percentage of independent } \\
\text { board members (Arayssi et al., 2020) }\end{array}$ \\
\hline BTEN & $\begin{array}{l}\text { The length of time for } \\
\text { which a director holds } \\
\text { the office of a director }\end{array}$ & $\begin{array}{l}\text { The average number of years each } \\
\text { board member has been on the } \\
\text { Board (Khan et al., 2019) }\end{array}$ \\
\hline DIV & $\begin{array}{l}\text { The proportion of } \\
\text { women directors }\end{array}$ & $\begin{array}{l}\text { The percentage of females on the } \\
\text { board (Arayssi et al., 2020; Isidro \& } \\
\text { Sobral, 2015; Valls Martínez et al., } \\
\text { 2019) }\end{array}$ \\
\hline
\end{tabular}

\section{Control Variables}

To avoid model misspecification, we control for additional variables that could influence the ESG score. Therefore, the analysis includes several control variables representing the corporate size (SIZE), profitability (PROF), and leverage (LEV).

The firm's size was measured as the natural logarithm of total assets at the end of the period (Arayssi et al., 2020; Hillman et al., 2007; Valls Martínez et al., 2019). The relation of company's size on ESG score has been researched by Tamimi and Sebastianelli (2017) for the United States sample, concluding that large companies have significantly higher ESG disclosures and receive higher ESG scores than middle or small companies.

To represent profitability, the variable chosen was return on assets, measured on 31 December for each year studied as an indicator of how profitable a company is relative to its total assets (Arayssi et al., 2020). The return on asset ratio is used to describe the efficiency of a company utilizing its assets for its operational activities.

The total debt-to-equity ratio is used to evaluate a company's financial leverage. This is the total debt ratio at the end of the fiscal period to total equity for the same period and is expressed as a percentage (Arayssi et al., 2020). It compares a company's total liability to its shareholder equity and can determine how much leverage a company uses. Higher leverage 
MANAGEMENT SCIENCES

Vol. 12, No. 1, 2022, E-ISSN: 2225-8329 @ 2022 HRMARS

ratios indicate a company facing a higher cost of capital as debt implies higher risk. A more highly leveraged firm might prioritize debtholders over other stakeholders, thus engaging less ESG (Haque, 2017).

\section{Empirical Results and Discussion Descriptive Analysis}

Table 2 presents the descriptive statistics for all variables used in this study. It is found that, on average, the ESG score is 51.60 , and it has high variation, as shown by a standard deviation of 15.74. The ESG scores range from a minimum of 6.14 to a maximum of 87.16 . This study finds that the Malaysian companies have 9 directors and around $52 \%$ of the board of directors' members are independent directors. The average board tenure is 7.8 years, with maximum board tenure of 23.5 years.

Regarding gender diversity, the average and maximum female directors are around $24 \%$ and $57 \%$ of the total directors, respectively. It is also found that the average size of the companies measured as Total Assets is RM68,562.30 million, and there is a large degree of variability in size with a standard deviation of RM141,311.67 million. The total assets of the companies under review are between the range of RM863.77 million to RM834,413.02 million. The profitability of the companies, which is measured using a return of assets (ROA), indicates that the average ROA of the sample is $5.18 \%$. The findings of this study suggest that the companies are highly geared as the average debt-to-equity ratio is $93.54 \%$.

Table 2. Descriptive Statistics.

\begin{tabular}{lcccc}
\hline & Mean & Min & Max & Std Dev \\
\hline ESG & 51.60 & 6.14 & 87.16 & 15.74 \\
BSIZE & 9.16 & 1.00 & 13.00 & 2.06 \\
IND & 52.20 & 0.00 & 78.57 & 13.23 \\
BTEN & 7.80 & 0.50 & 23.50 & 4.90 \\
DIV & 23.92 & 0.00 & 57.14 & 12.01 \\
SIZE (RM million) & 68562.30 & 863.77 & 834413.02 & 141311.67 \\
PROF & 5.18 & -35.87 & 43.98 & 8.85 \\
LEV & 93.54 & 0.49 & 780.29 & 115.49 \\
\hline
\end{tabular}

\section{Correlation Matrix}

Table 3 displays the Pearson parametric coefficients, and the results present the correlation coefficient for the variables selected in the regression analysis to examine the multicollinearity issue. It is found that the dependent variable (ESG score) has a significant and positive relationship with independent directors (IND), and there is a weak significant relationship between ESG and board characteristics, namely average board tenure (BTEN) and gender diversity (DIV). In terms of the control variables, there is a strong positive significant correlation between ESG score and total asset SIZE. However, the results show no correlation between ESG score and profitability of the companies. Since the highest correlation is -0.305 , the correlations among the variables of this study are relatively low, implying that the multicollinearity problem is not an issue. A severe multicollinearity problem exists if there are high correlations among the variables (Hair et al., 2013), as generally indicated by correlation coefficients of 0.90 and above. 
MANAGEMENT SCIENCES

Vol. 12, No. 1, 2022, E-ISSN: 2225-8329 @ 2022 HRMARS

Table 3. Correlation Matrix.

\begin{tabular}{|c|c|c|c|c|c|c|c|c|}
\hline & ESG & BSIZE & IND & BTEN & DIV & SIZE & PROF & LEV \\
\hline ESG & 1 & & & & & & & \\
\hline BSIZE & 0.055 & 1 & & & & & & \\
\hline IND & $* * * 0.291$ & -0.005 & 1 & & & & & \\
\hline BTEN & $*_{-0.145}$ & -0.124 & -0.069 & 1 & & & & \\
\hline DIV & *0.149 & -0.016 & -0.040 & -0.121 & 1 & & & \\
\hline SIZE & $* * * 0.276$ & $\begin{array}{c}* 0.129 \\
* * *\end{array}$ & $* * 0.190$ & -0.065 & 0.074 & $\begin{array}{c}1 \\
* * *\end{array}$ & & \\
\hline PROF & 0.092 & -0.200 & $\begin{array}{c}-0.110 \\
* * *\end{array}$ & 0.014 & 0.028 & -0.305 & 1 & \\
\hline LEV & *0.133 & -0.040 & -0.260 & -0.042 & 0.096 & 0.079 & 0.086 & 1 \\
\hline
\end{tabular}

\section{Regression Analysis}

This study used multiple regression analysis to examine the impact of board characteristics on ESG score using the following regression model after controlling for the company size, profitability, and leverage:

ESGit $=\alpha+\beta_{1}$ BSIZE $_{i t}+\beta_{2} I_{N D_{i t}}+\beta_{3}$ BTEN $_{i t}+\beta_{4}$ DIV $_{i t}+\beta_{5}$ SIZE $_{i t}+\beta_{6}$ PROF $_{i t}+\beta_{7} L_{E V} V_{i t}+\varepsilon$

Table 4. Multiple Regression

\begin{tabular}{lccc}
\hline & Coefficients & t Stat & P-value \\
\hline Intercept & -11.591 & -0.928 & 0.355 \\
BSIZE & 0.478 & 0.864 & 0.389 \\
IND & 0.367 & 4.130 & $0.000^{* * *}$ \\
BTEN & -0.265 & -1.155 & 0.250 \\
DIV & 0.148 & 1.587 & 0.115 \\
SIZE & 1.457 & 3.179 & $0.002^{* * *}$ \\
PROF & 0.349 & 2.610 & $0.010^{* * *}$ \\
LEV & 0.023 & 2.230 & $0.027^{* *}$ \\
\hline Adj. R sq & 0.195 & & \\
F value & 6.658 & & \\
\hline
\end{tabular}

$* * *$ significant at 0.01 level, ${ }^{* *}$ significant at 0.05 level, $*$ significant at 0.10 level

Table 4 presents the regression result for the relationship between board characteristics and ESG scores. The board characteristics considered in this study include board size, board independence, board tenure, and diversity. The results show no significant relationship between board size (BSIZE) and ESG score $(t=0.864)$. This result is in line with Sankara et al. (2017). It is suggested the number of board members does not influence the disclosure on ESG. Regardless of the board size, the companies can coordinate, communicate, and monitor their ESG disclosure.

Concerning board independence and ESG score, it is found that there is a strong positive significant relationship between board independence (IND) and ESG score ( $t=4.130)$. The findings of this study are consistent with Khaireddine et al. (2020). The existence of 
MANAGEMENT SCIENCES

Vol. 12, No. 1, 2022, E-ISSN: 2225-8329 @ 2022 HRMARS

independent boards may improve efficiency to stakeholders by mitigating agency conflicts (Jensen and Meckling, 1979), increasing voluntary disclosure (Samaha et al., 2015), greater multiplicity to corporate boards in terms of knowledge, expertise and networking (Ntim \& Soobaroyen, 2013). Consistent with stakeholder theory, the independent board has a stewardship responsibility to ensure the interest of the stakeholders are safeguarded (Khaireddine et al., 2020) through a higher level of ESG disclosure.

Even though the findings in Table 4 display that the relationship between board tenure (BTEN) and ESG score is negative, this relationship is not statistically significant ( $t=-1.155)$. This finding is aligned with prior literature that has found no significant relationship between board tenure and disclosure (Dewayanto et al., 2020; Hassan et al., 2020). This implies that the average number of years does not influence the disclosure level. Although long tenure may be beneficial as board members have better interaction and information (Rutherford \& Buchholtz, 2007), longer tenure may detrimentally affect the directors' quality (Clements et al., 2018). Since the board of directors comprises directors typically with different tenure lengths, more extended tenure benefits may be offset against their drawbacks. Thus, this study is inconsistent with Ratri et al (2021), who find a negative relationship between board tenure and disclosure level.

Table 4 shows no significant relationship between the diversity of board (DIV) regarding gender and ESG Score $(t=1.587)$. The result is in line with Manita et al $(2018)$, which find an insignificant relationship between gender diversity and voluntary disclosure. This study does not support previous research. The proposed female directors have better monitoring skills (Aribi et al., 2018), efficient (Tejedo-Romero \& Araujo, 2018), and positively influence responsible behaviour (Braz et al., 2018) that may eventually enhance the disclosure level. Hence, the ESG score is not influenced by the diversity of the directors.

Several control variables, namely firm size, profitability, and leverage have been considered in this study. It is found that all these control variables have a significant impact on the level of ESG score. In line with prior literature, ESG disclosure is positively and significantly influenced by size (Shahab \& Ye, 2018; Shakil et al., 2020; Steenkamp et al., 2019). More prominent companies have sufficient resources and facilities to provide more information on their activities related to ESG. Regarding profitability, this study suggests that the companies' profitability significantly impacts ESG scores. The finding is similar to Ratri et al. (2021). Profitable companies are inclined to have higher voluntary disclosure to reduce information asymmetry by disseminating more information to the stakeholders (Fakhari \& Pitenoie, 2017). Similar to Sulaiman et al. (2014), leverage level positively impacts the ESG disclosure level. Companies with higher leverage tend to have a higher level of ESG disclosure.

\section{Conclusions}

Rapid strides have been made in unlocking the business value of ESG in recent years. Firms are continuously receiving pressure from their stakeholders and must strategically address their ESG concerns to manage the pressures from various stakeholders. The board have a significant role to play in guiding management to allocate the appropriate resources and attention. Therefore, this study investigated the influence of board characteristics on ESG scores. We relied on the ESG scores released by Refinitiv Eikon Datastream. Using a sample of fifty-five (55) firms and applying empirical tests, we find that the percentage of 
MANAGEMENT SCIENCES

Vol. 12, No. 1, 2022, E-ISSN: 2225-8329 @ 2022 HRMARS

independent directors seems to be a substantial factor to explain the ESG score. This variable is statistically significantly and positively associated with the ESG score. Other board characteristics, however, is not associated with ESG score. Several control variables, namely firm size, profitability, and leverage have been considered in this study. It found that all control variables have a significant impact on ESG scores.

This paper has some limitations. First, the ESG score constructed by Refinitiv Eikon examines only publicly available information for publicly listed companies. Our theoretical and empirical findings probably are more applicable to publicly listed companies than exclusive ones. Secondly, we analyze board characteristics by considering the board size, independence, average board tenure, and diversity. Future studies might be based on other features, such as board background and skills, board-specific skills, board meetings, audit committees, and CSR committees. Yet, the sample size could be extended. Finally, our data is limited to Malaysia only. Further studies should explore the growth of ESG across Asia and other developing countries to integrate the findings of this study and formulate regulatory frameworks that allow better transparency and hence contribute to long-term stakeholder value.

\section{Acknowledgements}

The authors would like to thanks the financial support granted by the Universiti Teknologi MARA for this project.

\section{References}

Adams, R. B., \& Ferreira, D. (2009). Women in the boardroom and their impact on governance and performance. Journal of Financial Economics, 94(2), 291-309.

Ahmed, K., Hossain, M., \& Adams, M. B. (2006). The effects of board composition and board size on the informativeness of annual accounting earnings. Corporate Governance An International Review, 14(5), 418-431.

Arayssi, M., Jizi, M., \& Tabaja, H. H. (2020). The impact of board composition on the level of ESG disclosures in GCC countries. Sustainability Accounting Management and Policy Journal, 11(1), 137-161.

Aribi, Z. A., Alqatamin, R. M., \& Arun, T. (2018). Gender diversity on boards and forwardlooking information disclosure: evidence from Jordan. Journal of Accounting in Emerging Economies, 8(2), 205-222.

Bae, K.-H., El Ghoul, S., Gong, Z. (jason), \& Guedhami, O. (2021). Does CSR matter in times of crisis? Evidence from the COVID-19 pandemic.Journal of Corporate Finance, 67(101876), 101876.

Bătae, O. M., Dragomir, V. D., \& Feleagă, L. (2021). The relationship between environmental, social, and financial performance in the banking sector: A European study. Journal of Cleaner Production, 290(125791), 125791.

Bear, S., Rahman, N., \& Post, C. (2010). The impact of board diversity and gender composition on corporate social responsibility and firm reputation. Journal of Business Ethics, 97(2), 207-221.

Birindelli, G., Dell'Atti, S., lannuzzi, A., \& Savioli, M. (2018). Composition and activity of the Board of directors: Impact on ESG performance in the banking system. Sustainability, 10(12), 4699. 
MANAGEMENT SCIENCES

Vol. 12, No. 1, 2022, E-ISSN: 2225-8329 ๔ 2022 HRMARS

Branco, M. C., \& Rodrigues, L. L. (2008). Factors influencing social responsibility disclosure by Portuguese companies. Journal of Business Ethics, 83(4), 685-701.

Braz, M. J. O., \& Lopes, A. I. (2018). The relationship between board's diversity and the reputation of integrated reports. In XVIII Encontro Internacional AECA. Liboa: Asociasion Espanola de Contabilidad y Administracion de Empresas.

Clements, C. E., Jessup, R. K., Neill, J. D., \& Wertheim, P. (2018). The relationship between director tenure and director quality. International Journal of Disclosure Governance, 15, 142-161.

Dewayanto, T., Rahmawati, \& Suhardjanto, D. (2020). Intitutional ownership, blockholder ownership and the board's tenure to disclosure of corporate governance. Ekuilibrium: Jurnal IImiah Bidang Ilmu Ekonomi, 15(1), 83-90.

Drempetic, S., Klein, C., \& Zwergel, B. (2020). The influence of firm size on the ESG score: Corporate sustainability ratings under review. Journal of Business Ethics, 167(2), 333360.

Fakhari, H., Pitenoie, R. Y., Doi, F., H., \& Pitenoie, R. Y. (2017). The impact of audit committee and its characteristics on the firms' information environment. Iranian Journal of Management Studies, 10(3), 577-608.

Fama, E. F., \& Jensen, M. C. (1983). Separation of ownership and control. The Journal of Law \& Economics, 26(2), 301-325.

Freeman, R. E. (1984). Strategic Management: A Stakeholder Approach (p. 46). Boston: Pitman.

Hafsi, T., \& Turgut, G. (2013). Boardroom diversity and its effect on social performance: Conceptualization and empirical evidence. Journal of Business Ethics, 112(3), 463-479.

Hair, J. F., Black, W. C., Babin, B. J., \& Anderson, R. E. (2013). Multivariate data analysis: Pearson new international edition. Pearson.

Handajani, L., Subroto, B., Sutrisno, T., \& Saraswati, E. (2014). Does board diversity matter on corporate social disclosure? An Indonesian evidence. Journal of Economics and Sustainable Development, 5(12), 8-16.

Haque, F. (2017). The effects of board characteristics and sustainable compensation policy on carbon performance of UK firms. The British Accounting Review, 49(3), 347-364.

Harjoto, M., Laksmana, I., \& Lee, R. (2015). Board diversity and corporate social responsibility. Journal of Business Ethics, 132(4), 641-660.

Hassan, L. S., Saleh, M. N., \& Ibrahim, I. (2020). Board diversity, company's financial performance and corporate social responsibility information disclosure in Malaysia. International Business Education Journal, 13(1), 23-49.

Hillman, A. J., Shropshire, C., \& Cannella, A. A., Jr. (2007). Organizational predictors of women on corporate boards. Academy of Management Journal, 50(4), 941-952.

Huse, M., \& Solberg, A. G. (2006). Gender-related boardroom dynamics: How Scandinavian women make and can make contributions on corporate boards. Women in management review. 21(2), 113-130.

Isidro, H., \& Sobral, M. (2015). The effects of women on corporate boards on firm value, financial performance, and ethical and social compliance. Journal of Business Ethics, 132(1), 1-19.

Ismail, A. M., \& Latiff, I. H. M. (2019). Board diversity and corporate sustainability practices: Evidence on environmental, social and governance (ESG) reporting. International Journal of Financial Research, 10(3), 31-50. 
MANAGEMENT SCIENCES

Vol. 12, No. 1, 2022, E-ISSN: 2225-8329 ๔ 2022 HRMARS

Jensen, M. C., \& Meckling, W. H. (1976). Theory of the firm: Managerial behavior, agency costs and ownership structure. Journal of Financial Economics, 3(4), 305-360.

Johnson, R. A., \& Greening, D. W. (1999). The effects of corporate governance and institutional ownership types of corporate social performance. Academy of Management Journal, 42(5), 564-576.

Khaireddine, H., Salhi, B., Aljabr, J., \& Jarboui, A. (2020). Impact of board characteristics on governance, environmental and ethical disclosure. Society and Business Review, 15(3), 273-295.

Khan, I., Khan, I., \& Senturk, I. (2019). Board diversity and quality of CSR disclosure: evidence from Pakistan. Corporate Governance, 19(6), 1187-1203.

Mallin, C. A., \& Michelon, G. (2011). Board reputation attributes and corporate social performance: an empirical investigation of the US Best Corporate Citizens. Accounting and Business Research, 41(2), 119-144.

Manita, R., Bruna, M. G., Dang, R., \& Houanti, L. (2018). Board gender diversity and ESG disclosure: evidence from the USA. Journal of Applied Accounting Research, 19(2), 206224.

Naciti, V. (2019). Corporate governance and board of directors: The effect of a board composition on firm sustainability performance. Journal of Cleaner Production, 237(117727), 117727.

Ntim, C. G., \& Soobaroyen, T. (2013). Corporate governance and performance in socially responsible corporations: new empirical insights from a neo-institutional framework. Corporate Governance: An International Review, 21(5), 468-494.

Rao, K., \& Tilt, C. (2016). Board composition and corporate social responsibility: The role of diversity, gender, strategy and decision making. Journal of Business Ethics, 138(2), 327347.

Ratri, M. C., Harymawan, I., \& Kamarudin, K. A. (2021). Busyness, tenure, meeting frequency of the CEOs, and corporate social responsibility disclosure. Sustainability, 13(10), 5567.

Refinitiv Eikon Datastream. 2021. Available. http://www.refinitive.com/en/products/datastream-macroeconomics-analysis. (Accessed 23 January 2021)

Romano, M., Cirillo, A., Favino, C., \& Netti, A. (2020). ESG (Environmental, social and Governance) performance and board gender diversity: The moderating role of CEO duality. Sustainability, 12(21), 1-16.

Rutherford, M. A., \& Buchholtz, A. K. (2007). Investigating the relationship between board characteristics and board information. Corporate Governance An International Review, 15(4), 576-584.

Samaha, K., Khlif, H., \& Hussainey, K. (2015). The impact of board and audit committee characteristics on voluntary disclosure: A meta-analysis. Journal of International Accounting Auditing and Taxation, 24, 13-28.

Sankara, J. L., D., \& Nowland, J. (2017). Are board governance characteristics associated with ethical corporate social responsibility disclosure? The case of the mandatory conflict minerals reporting requirements. Journal of Leadership. Accountability and Ethics, 14(3), 101-116.

Shahab, Y., \& Ye, C. (2018). Corporate social responsibility disclosure and corporate governance: empirical insights on neo-institutional framework from China. International Journal of Disclosure and Governance, 15(2), 87-103. 
MANAGEMENT SCIENCES

Vol. 12, No. 1, 2022, E-ISSN: 2225-8329 ๔ 2022 HRMARS

Shakil, M. H. (2021). Environmental, social and governance performance and financial risk: Moderating role of ESG controversies and board gender diversity. Resources Policy, 72(102144), 102144.

Shakil, M. H., Tasnia, M., \& Mostafiz, M. I. (2021). Board gender diversity and environmental, social and governance performance of US banks: moderating role of environmental, social and corporate governance controversies. International Journal of Bank Marketing, 39(4), 661-677.

Shaukat, A., Qiu, Y., \& Trojanowski, G. (2016). Board attributes, corporate social responsibility strategy, and corporate environmental and social performance. Journal of Business Ethics, 135(3), 569-585.

Shiah-Hou, S.-R., \& Cheng, C.-W. (2012). Outside director experience, compensation, and performance. Managerial Finance, 38(10), 914-938.

Steenkamp, G., Dippenaar, M., Fourie, C., \& Franken, D. (2019). Share-based remuneration: Per-director disclosure practices of selected listed South African companies. Journal of Economic \& Financial Sciences, 12(1). doi:10.4102/jef.v12i1.400

Sulaiman, M., Abdullah, N., \& Fatima, A. H. (2014). Determinants of environmental reporting quality in Malaysia. International Journal of Economics, Management and Accounting, 22(1), 63-90.

Tamimi, N., \& Sebastianelli, R. (2017). Transparency among S\&P 500 companies: an analysis of ESG disclosure scores. Management Decision, 55(8), 1660-1680.

Tejedo-Romero, F., \& Araujo, J. F. (2018). Transparency, social responsibility and corporate governance: human capital of companies. Cuadernos de Gestion, 18(2), 133-162.

Teplova, T., Sokolova, T. V., \& Munir, Q. (2020). Eikon Refinitiv, Bloomberg and Cbonds databases for solving research problems. In Emerging Bond Markets (pp. 306-323). Routledge.

Terjesen, S., Sealy, R., \& Singh, V. (2009). Women directors on corporate boards: A review and research agenda. Corporate Governance An International Review, 17(3), 320-337.

Valls Martínez, M. del C., \& Cruz Rambaud, S. (2019). Women on corporate boards and firm's financial performance. Women's Studies International Forum, 76(102251), 102251.

Velte, P. (2016). Women on management board and ESG performance. Journal of Global Responsibility, 7(1), 98-109.

Von Arx, U., \& Ziegler, A. (2014). The effect of corporate social responsibility on stock performance: new evidence for the USA and Europe. Quantitative Finance, 14(6), 977991.

Ward, A. M., \& Forker, J. (2017). Financial management effectiveness and board gender diversity in member-governed, community financial institutions. Journal of Business Ethics, 141(2), 351-366.

Zhang, J. Q., Zhu, H., \& Ding, H.-B. (2013). Board composition and corporate social responsibility: An empirical investigation in the post Sarbanes-Oxley era. Journal of Business Ethics, 114(3), 381-392.

Zuraida, Z., Houqe, N., \& van Zijl, T. (2016). Value relevance of environmental, social, and governance disclosure. SSRN Electronic Journal. doi:10.2139/ssrn.2722917 